\title{
The Strategy of Improving the Information Literacy of Private College Students in the Big Data Era
}

\author{
Bo Xiao \\ Guangdong University of Science \& Technology, Dongguan, 523083, China \\ xiaobo198388@163.com
}

Key words: private colleges and universities; students; information literacy; promotion strategy

\begin{abstract}
The 21st century is the era of information explosion. The rapid development of information technology and network technology, the rapid growth of information, the intelligence of processing, the globalization of communication and the large data processing and application have great impact on economic development of modern society. This also puts forward higher requirements to people's information literacy. This paper analyzes the present situation and existing problems of students 'information literacy in private colleges and universities, and puts forward the strategies to improve the students' information literacy ability of private colleges and universities.
\end{abstract}

\section{Introduction}

College students are not only the knowledge groups of today's society, but also the future builders and successors of the country, the reserve talents of national reform and innovation. Only with good information literacy ability can we meet the development requirement of today's big data age. Therefore, contemporary college students have the ability of information collection from various channels, objective evaluation of information and the correct use of information, following a good code of ethics. This ability is particularly important. College students information literacy problem is imminent.

\section{Information Literacy Problems in Private Universities in the Big Data Era}

Through the analysis of the information literacy literature and the status quo of the research, the information literacy ability of the private college students in our country is still relatively low, which is embodied from the following aspects:

\subsection{The state is lack of attention to information literacy of private school students ;}

2.1.1 The state hasn' $t$ a unified standard of judgment on the information literacy of contemporary college students.

Each researcher relies on his own views and his own knowledge field to evaluate the analysis, but it is unique but lacks authority. The whole country has not been able to establish a recognized and mature evaluation system of college students' information literacy.

2.1.2Theory departs from reality.

Most of the researchs done by scholars in recent years are based on CNKI and Wanfang's huge database. There are many theoretical problems, but the practical value is not high. There is a lack of real field research, or research coverage is not enough, which causes the disability of meeting the requirements of the times.

2.1.3 learning pressure is too large, lack of effective regulation of information literacy

Now college students in China, facing the background relying on the ability to test the strengths and weaknesses, have been under enormous pressure to learn and grow. They have long been accustomed to only value the books. Even though they get into a relatively free university, they have to face all kinds of challenges like the test of postgraduate and qualification certificate and stuff. They themselves, family, society have ignored the training of their information literacy ability . 


\subsection{Information literacy education infrastructure of private colleges and universities is still very weak}

Compared with the public schools, the private colleges and universities have a disadvantage in terms of capital, technology, policy support and talent, so the problem of information literacy of college students is more serious.

2.2.1 Most of the private schools have not yet put the students' nformation literacy skills into the students' one-year assessment criteria.

2.2.2 The quality of students in private schools is certainly different from that in public schools. Many famous university students have this quality and habits. Furthermore, school spirit is not the same as private schools. Private schools are mostly advocated out;

2.2.3 Some private institutions do not have the strength of the relevant information literacy training courses, but also have the lack of appropriate curriculum teachers; even though some schools open the course, information literacy education content is also very simple, the method is too simple and lack of practice. It usually adopts the form of lecture to teach theoretical knowledge, rarely teaches them how to find the literature. As to the use of commonly used search tools, there is no corresponding assessment methods.

2.2.4 Practical value of the library is not high

The outside and inside of many private libraries are inconsistent. The outside is magnificent, while the internal library and public search tools are indeed lacking. Computer replacement cycle is too long, besides, freshmen lack library daily use of education. Though they live on campus for some time, they know little about library collection, search tools, search methods, resulting in that zation of information resources is not high. It is difficult to enhance the capacity of the library information literacy to play its due role.

\section{3 teachers' lack of information literacy, lack of promotion of the way}

Teachers serve as the subject of the transfer to the industry doubts, and their information literacy will have a direct impact on students at all times.

2.3.1 Many teachers have not yet changed the concept, still have been stuck in the past traditional thinking, which will not help them adapt to the pace of the times. Private colleges and universities do not open regular upgrade courses for teachers, and even some old teachers don' $t$ know how to use normal office software and checking the literature depends on the books of the library.

2.3.2 Education way always keeps the same.

Teachers of private colleges and universities sometimes use some textbooks or PPT, but they have the lack of interaction with the students. There is an old saying "it is much better to teach people fishing than offer them fishes” . Teachers can pass their own knowledge-seeking methods to their students, then students use these methods or other modern network resources to attain knowledge, but also they can share knowledge with the teacher. The teachers then evaluate these ways to further improve their own education, expand their knowledge and make common progress to achieve a virtuous circle.

\section{4 students lack the ability of their own information literacy}

Compared with the students of public school, students of private schools have poor selfdiscipline. In the era of large data, they face overwhelming information. They have the lack of the ability to judge useful information and their understanding ability is relatively poor. When they decide "right" or "wrong”, they mindlessly follow the trend, such as: selling other people's products online, forwarding rumors, etc . There are students without the ability to get information. They just only lose themselves in their own world, where they do not touch the community and show no concern for the state policy. Such students often show the poor social ability. What's more, some individual student has a serious lack of information literacy, maliciously changes other students' computer settings, spreads the filthy video images and makes an online fraud. Therefore, enhancing the contemporary information technology literacy of college students is extremely urgent. 


\section{Strategies to improve the information literacy of students in private colleges and universi- ties}

In view of the above problems, this paper puts forward the following suggestions and countermeasures:

3.1 Appeal to the whole society to participate in the information literacy promotion action, and increase the national education sector to support the policy of private schools

In China, policy orientation in process of the event planning and implementation plays a vital role. In order to enhance the nation's overall information literacy ability of college students, it should break the "gateway" to increase support for private schools rather than just relying on the school to bear. In addition, family environment and social environment are perfect places about cultivating contemporary college students, so we should do the following:

3.1.1 To establish three correct views and rely on appropriate social public opinion to nurture a positive, healthy, upward moral atmosphere;

3.1.2 Strengthen the network public opinion monitoring from the source to control spreading around unhealthy and harmful information to avoid poisoning others.

3.1.3 Increase the intensity of the punishment of cybercrime and depend on the law to restrain our national behavior, so that we can realize the legitimate online and civilized Internet.

3.2 The school should promptly open the information literacy education curriculum, and determine the annual education goals and assessment programs

3.2.1 Colleges and universities should rationally use library resources and open information literacy courses, meanwhile, make a clear claim that the course is compulsory for college students to determine the qualifications of teachers and class hours, evaluation requirements.

3.2.2 The use of library resources, information literacy publicity and education for college students aims to promote practical courses such as information technology; Now many of the students are the generations after 90 s or even 00s, so they are more obvious to pursue the vitality, interest and convenience of network resources. It is necessary to encourage teachers to use multimedia and other new media platform to impart knowledge to college students to increase the frequency of interaction between teachers and students. The establishment of network information resources navigation and guiding students to correctly use the internet resources to improve the utilization of information resources are urgent.

3.2.3 To increase the intensity of the construction of university teachers, college teachers as a student leader, must keep pace with the times and link interdisciplinary fields. Besides, colleges and universities should also arrange teachers to practice training in order to continue improving their own knowledge system, have a good grasp on the new era of retrieval technology and methods and improve their information literacy capacity. In addition, regularly provide teachers and students with interactive platform to help teachers really blend in with students and guide students to correct screening, acquisition, absorption and utilization of information resources, with the aim of training them to use information to solve problems independently.

\subsection{To encourage students to do independent innovation research}

School-based information literacy courses should teach college students basic information retrieval methods, on the basis of which teachers and parents further guide them to obtain valuable information, so that they get rid of "confused" (do not know what they need, how to get it, what is the use of information) At the same time, teachers and parents subtlely influence them and help them understand their own moral bottom line, and establish self-confidence of alone hunting information. What' $s$ more, encourage them to try new methods with the premise of not violating the morals and laws, to get the information resources and inspire their sense of innovation, ignite their enthusiasm for innovation, so that they can take the initiative to enhance their information literacy skills, get rid of the embarrassing situation - a push a move. 


\section{Summary}

This paper describes the current situation and existing problems of information literacy at home and abroad private colleges and universities, analyzes the problems in information literacy of private universities from the aspects of society, family, teachers quality and students quality. In the end, the paper puts forward some suggestions and countermeasures, however,there are still some drawbacks, especially the practice data collection, such as the weakest field of students' information literacy,the most popular information literacy education ways for students, etc. I will spare no effort to continue to study.

\section{References}

[1] SHI Ying-xia.Party on the Current Situation of Network Media Literacy of Student Party Members in Private Colleges and Universities and Educational Countermeasures [J]. Journal of Lianyungang Vocational and Technical College, 2016,02: 59-62.

[2] Xia Jiao, Lu Yanxia, Wu Ze-shu, Zhang Ming-hui .On the Quality Education of Private University Students [J] .Computer Education, 2013,09: 8-12.

[3] Zhang Jingbo. Data Literacy Education in the Big Data Age [J]. Science, 2013,04: 29-32 + 4. [4] Chi Chun-li, Chi Chun-xia.The Current Situation of Media Literacy of College Students and Its Optimization Strategy - Based on the Investigation of Shanghai Private Colleges [J]. Journal of Shanghai Business College, 2013,03: 92-96.

[5] Zhang Lijuan. Private Higher Vocational College students of humanistic quality education research [D]. Nanjing Normal University, 2014.

[6] Zhang Chunli. University information retrieval course practice innovation method research [D]. Anhui University, 2013.

[7] Xiong Hui. Large data age private university students information literacy strategy research [D]. Xiangtan University, 2015. 